\title{
Feasibility study of the application of treated wastewater for the irrigation of forest species in a Saharan area
}

\author{
Hamza Negais $^{1^{+}}{ }^{\circledR}$, Tahar Idder $^{\circledR}$, Hamid Cheloufi $^{1^{\circledR}},{\text { Abdelhak } \text { Idder }^{\circledR}}^{\circledR}$, Slimane Ahmed Benmchi'h Ayada $^{2^{\circledR}}$ \\ ${ }^{1}$ Department of Biology, Laboratory of Phoeniciculture Research, University of Ouargla, Kasdi Merbah, BP 511, Ouargla, Algeria \\ ${ }^{2}$ High Commissionership for Development of the Steppe (HCDS), Djelfa, Algeria
}

\begin{abstract}
Background: After suffering from an acute problem of excess water for a long time, the Oasis of Ouargla benefited from an aerated lagoon treatment plant, producing biologically treated domestic effluents. The aim of this study was to examine the feasibility of reusing this effluent for watering plants. The experiment was conducted in the Ouargla WWTP, which is located in the region of Said Otba (northeast of Ouargla), north of the national road NR 49.

Methods: The study area was selected based on the originality of the study and availability of water. The plants used were Acacia farnesiana and Leucaena leucocephala. The selection of Leucaena was based on the following criteria: It is used as a windbreak, it is very tolerant to drought, and it is used as a fodder to maintain soil fertility. And, Acacia was selected because it is used as a fodder, protects the soil against erosion, and to fix nitrogen. The watering of these plants is done jointly by treated wastewater from the WWTP and well water (WW), of which the latter was used as a control. Sampling and analysis of the irrigation water were performed according to the experimental protocol. To show the growth rate of the two plants studied, biometric measurements were taken weekly for 25 weeks.

Results: The physicochemical analyses show that the treated wastewater is of poor quality belonging to the last class of Riverside's C5-S4, with an excessive salinity (EC) of $13.51 \mathrm{dS} / \mathrm{m}$ and an Sodium adsorption ratio (SAR) of 12.61 against EC of $2.49 \mathrm{dS} / \mathrm{m}$ and 2.13 for the WW. At the end of the experiment, it was found that irrigation with purified wastewater (PWW) gave less growth compared to that with WW. Statistical analyses of the biometric measurements confirmed that there is a highly significant difference at $P<0.05$.

Conclusion: The reuse of WWTP effluent gives less interesting results but is still possible. It is recommended to choose Salt-tolerant crops, as well as the dilution of these waters by the addition of less salty waters.

Keywords: Well water, Treated waste water, Forest species, Irrigation Saharan area, Wastewater reuse Citation: Negais H, Idder T, Cheloufi H, Idder A, Benmchi'h Ayada SA. Feasibility study of the application of treated wastewater for the irrigation of forest species in a Saharan area. Environmental Health Engineering and Management Journal 2021; 8(3): 197-204. doi: 10.34172/EHEM.2021.23.
\end{abstract}

\section{Introduction}

In the next fifty years, more than $40 \%$ of the world's population will live in countries facing water scarcity $(1,2)$. Growing competition between agricultural and urban uses increases the pressure on this scarce resource, particularly in arid or semi-arid regions with high population density (2).

The theoretical threshold of scarcity set by the World Bank at $1000 \mathrm{~m}^{3}$ per capita per year places Algeria among the poorest countries in terms of water potential (3). Agriculture is the first consumer of water, with nearly $65 \%$ of withdrawals at the national level, which make the reuse of purified wastewater (PWW) for irrigation as a priority in the new Algerian water policy $(4,5)$.

One of the most recognized benefits of using wastewater in agriculture is the associated decrease in pressure on freshwater resources. Thus, wastewater used as an alternative source (6-8). In addition, nutrients exist in wastewater help to save fertilizer costs (9-12).

The establishment of greenbelts around cities by forest trees irrigated by wastewater serves to revive the ecological balance and improves environmental conditions by selftreatment of wastewater through the practice of forest irrigation (13). Forest trees may be more tolerant of wastewater irrigation than other plants (14). However, their ability to survive and grow seems to vary between species, due to their unwanted constituents such as salts, trace elements, organic compounds, pathogens, etc. (15). The use of wastewater in forestry and agroforestry holds great promise, but much research is needed before this 
potential can be realized (16). The use of this resource requires research to determine its short- and longterm effects on the nature and production of soil and groundwater, and the effects of changes in these effluents on tree growth (17). Ayers and Westcot (18) have placed great emphasis on the need for careful monitoring and evaluation of this type of irrigation. Thus, the use of wastewater must be safe since it is rich in pathogens including parasites (19), bacteria, viruses, protozoa, and helminths (20), and the plots must be kept away from WWTPs, since they are colonized by airborne fungi (21).

On the other hand, Ouargla, a city in the Sahara desert (southern Algeria), suffered from the problem of excess water due to poorly managed urban and agricultural discharges (22-25). Consequently, the Algerian state started the development project, which consisted, in particular, in the construction of agricultural drainage networks, sanitation networks, and the installation of a treatment plant by aerated lagoon, which is able to produce effluents that comply with the standards required for wastewater reuse for agricultural purposes (26). This WWTP plant produces domestic PWW with a volume of $13505000 \mathrm{~m}^{3} /$ year (27). It has been reported that the flow exploited in the Ouargla basin has practically increased by 3 times between 1970 and 2010, and by 7 times between 1888 and 2010 (28), and the total volume used in Ouargla for agricultural needs (43704000 $\mathrm{m}^{3} /$ year) is enormous (29). We could save $30 \%$ of total volume used in agriculture, creation of peri-urban green spaces or in forestry for the production of timber or treatment wastewater by phytoremediation as the pilot project "constructed wetlands" in the oasis of Brézina (El Bayadh). This project aimed to develop a small plantation of tamarisk intended for the production of bioenergy, through the use of treated wastewater (30).
The aim of this study was to examine, on a small scale, the possibility of reusing the effluents from the Ouargla treatment plant for irrigating forest species such as Acacia farnesiana and Leucaena leucocephala. The experiment was based on the evaluation of vegetative behaviour through the comparison of biometric measurements in particular, the rate of growth in height and diameter of the plants irrigated in parallel with PWW and WW as control.

\section{Materials and Methods \\ Study area}

The city of Ouargla is located in the south-east of Algeria (31). It extends over approximately $30 \mathrm{~km}$ long and 12 to $18 \mathrm{~km}$ wide, at an altitude varying from 103 to $150 \mathrm{~m}$ (32). The climatic study of the study region shows that it is located in the Saharan bioclimatic stage, where the monthly average temperature of the hottest month (July) exceeds $36^{\circ} \mathrm{C}$ and that of the coldest month (January) is $12.07^{\circ} \mathrm{C}$. The annual precipitation is $38 \mathrm{~mm}$. January is the wettest month with a value of $9.35 \mathrm{~mm}$ and July is the driest month with a value of $0.35 \mathrm{~mm}$. In addition, the sunstroke, evaporation, and the wind, which characterize the Saharan environment, generate a water deficit and a dry period for this region.

This study was performed in the Ouargla WWTP (Figure 1), which is located in the region of Said Otba (northeast of Ouargla), north of the national road NR 49 and its commissioning dates back to 2009 . Its objectives are the elimination of nuisances and risks of contamination in urban areas, the protection of the receiving environment, and reusing the treated effluents in irrigation.

At the WWTP, the raw wastewater undergoes extensive biological treatment by aerated lagoon. This lagoon is composed of a pre-treatment compartment (screening

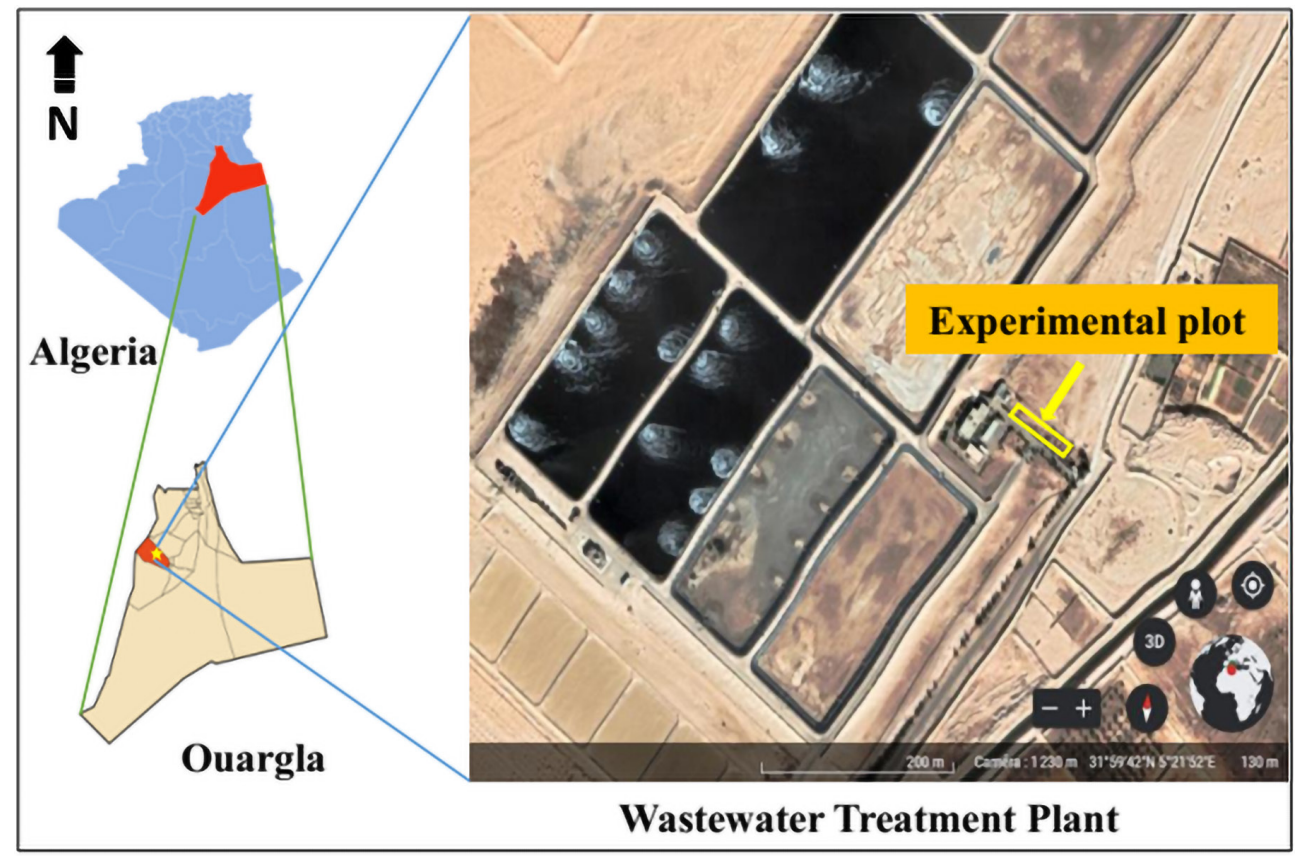

Figure 1. Location map of Algeria, WWTP of Ouargla, and the experimental plot. 
and grit removal) where the wastewater passes through two screens, which retain the most voluminous matter carried, by the raw water. To remove gravel, sand, and fine mineral particles, the raw water passes through a grit chamber. This is followed by three levels of treatment in which the biodegradable load of the effluent is destroyed by a bacterial way, whose microbial activity is accelerated by the artificial aerators.

\section{Experimental dispositive}

In this test, the block dispositive was used. The experimental plot was divided into two blocks: The first block were the plants of the two species watered with PWW, and the second one, playing the role of control, were the plants of the same two species watered with well water (WW). The implantation of the plants was random, so that each individual represents a repetition. The number of plants was 24 per species and per block. The total number of individuals was 96 implanted in a plot with an area of $448 \mathrm{~m}^{2}$ (Figures 2 and 3). The soil of this plot was bare soil of sandy texture, very salty with a surface accumulation profiles (SAP) (33).

\section{Irrigation water analysis}

The method of sampling varies depending on the type of analysis. For the PWW, the sample was taken manually

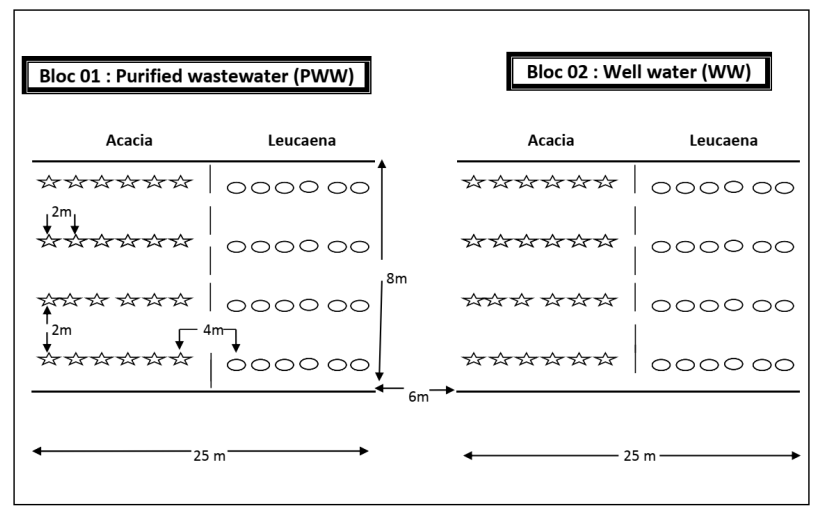

Figure 2. Plan of experimental dispositive.

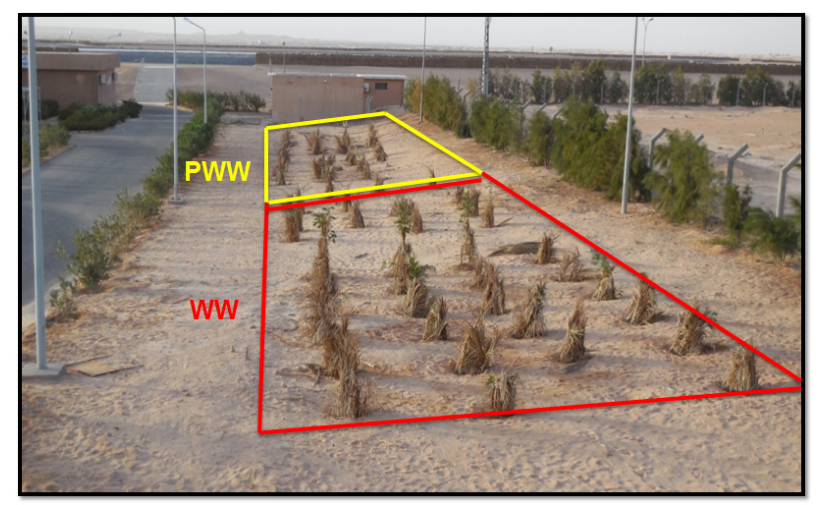

Figure 3. General view of the experimental plot. at the outlet of the WWTP's finishing basin. For this purpose, using a small container, two liters of the PWW was taken and kept in a cooler during the transport to laboratory. The containers used for this purpose were clean glass bottles sterilized beforehand, on which the place and date of sampling of the water were labelled. The WW was taken from the tap located near the experimental plot. This approach, concerning the transport and storage of samples intended for analysis, refers to the methods described by Rodier(34).

These types of water have undergone analyses of the following parameters: Electrical conductivity (EC), $\mathrm{pH}$, and cations and anions: $\mathrm{Ca}^{2+}, \mathrm{Mg}^{2+}, \mathrm{Na}^{+}, \mathrm{K}^{+}, \mathrm{Cl}^{-}, \mathrm{HCO}_{3}$ $, \mathrm{NO}_{3}^{-}, \mathrm{SO}_{4}^{-2}$. Regarding the pollution parameters (COD, $\mathrm{BOD}_{5}$, and SS), they were only made for PWW and WW, whose analyzes were performed according to the methods described by Rodier(34) for the analysis of water.

\section{Used vegetation}

These species belong to the Fabaceae. The plant selection was based on the following criteria:

For Leucaena, it is used as a windbreak, it is very tolerant to drought, and it is used as a nutritious fodder for feeding ruminants $(35,36)$, and to maintain soil fertility (36). For Acacia, it is an invasive species used as fodder for livestock, to protect the soil against erosion (37), and to fix nitrogen (38).

To show the growth rate of the two plants studied, the height and diameter parameters were measured and recorded. Plant height was measured using a meter from crown to terminal burgeon, and plant diameter was measured using a caliper. During 25 weeks of follow-up (from April to September), biometric measurements were performed weekly in the morning.

The watering frequency and the water volume were based on the water requirements estimated from the maximum evapotranspiration (MTE). The irrigation of the plants was performed using simple submersion in the evening.

\section{Statistical analysis}

The results obtained from these biometric measurements were interpreted statistically using independent samples $t$ test with a $95 \%$ confidence interval (CI), by SPSS version 27, 2020.

\section{Results}

\section{Irrigation water}

The results of the physicochemical analyses performed on the two types of irrigation water used in the context of this experiment are summarized in Table 1.

The graphical representation of the two samples in the Riverside's diagram (Figure 4) shows that the PWW belongs to the last class C5-S4, which is the same class defined by Nader (39) and Bouhana et al (40). This type of water presents the risk of high salinization. On the other 
Table 1. Physicochemical characteristics of irrigation water

\begin{tabular}{|c|c|c|}
\hline Parameters & PWW & WW \\
\hline $\mathrm{pH}$ & 7.87 & 7.3 \\
\hline $\mathrm{EC}(\mathrm{dS} / \mathrm{m})$ & 13.51 & 2.49 \\
\hline SAR & 12.61 & 2.13 \\
\hline $\mathrm{Ca}^{+2}(\mathrm{meq} / \mathrm{L})$ & 12.06 & 7.28 \\
\hline $\mathrm{Mg}^{+2}(\mathrm{meq} / \mathrm{L})$ & 1.95 & 2.05 \\
\hline $\mathrm{Na}^{+}(\mathrm{meq} / \mathrm{L})$ & 108.91 & 11.41 \\
\hline $\mathrm{K}^{+}(\mathrm{meq} / \mathrm{L})$ & 4.83 & 0.38 \\
\hline $\mathrm{Cl}-(\mathrm{meq} / \mathrm{L})$ & 106 & 11.97 \\
\hline $\mathrm{HCO}_{3}-(\mathrm{meq} / \mathrm{L})$ & 9 & 2.95 \\
\hline $\mathrm{NO}_{3}^{-}(\mathrm{meq} / \mathrm{L})$ & 4 & 4.8 \\
\hline $\mathrm{SO}_{4}^{-2}(\mathrm{meq} / \mathrm{L})$ & 11.31 & 3.25 \\
\hline COD (mg/L) & 132.95 & \\
\hline BOD5 (mg/L) & 27.43 & \\
\hline SS (mg/L) & 90.23 & \\
\hline
\end{tabular}

SS: Suspended solids or solid particles; PWW: purified wastewater; WW: well water; SAR: sodium adsorption ratio; EC, electrical conductivity; COD: chemical oxygen demand; BOD5: biological oxygen demand over 5 days.

hand, WW belongs to class C4-S2, which corresponds to water with a mediocre to bad quality.

\section{Height growth monitoring}

Biometric measurements on Acacia farnesiana during throughout the duration of the experiment show two distinct phases of plant growth (Figure 5):

The first phase over the first 7 weeks of follow-up after planting where there is poor growth for all individuals and a non-significant difference between the treatments. This phase corresponds to a phase of adaptation of individuals to their new environment (transition from nursery conditions to natural conditions, particularly with regard to the exposure to the sun and wind).

The second phase from the 8 th week until the end of the experiment where the treatment effect is significant. In this phase, the plants watered with WW experienced a high growth rate compared to those irrigated with PWW. The average height of the plants reached $109.94 \mathrm{~cm}$ for the first treatment compared to $54.47 \mathrm{~cm}$ for the second one, about double the size of each other. Statistical analysis shows that there is a significant difference in the height $(P<0.05)$.

Biometric measurements on Leucaena leucocephala during the experiment show a single phase of plant growth with, however, an amplification of the difference between the treatments over time (Figure 6). At the end of the experiment, Leucaena watered with WW reached an average height of $76.12 \mathrm{~cm}$ compared to the plants irrigated by PWW with an average height of $46.54 \mathrm{~cm}$. The difference is statistically significant $(P<0.05)$.

Ultimately, plants irrigated with WW had greater height growth compared to those irrigated with PWW; Acacia farnesiana behaved better in the Saharan edapho-climatic conditions compared to the other species.

\section{Growth monitoring in diameter}

The biometric measurements of the diameter performed during the experiment as well as the height of the plants confirmed the beneficial effect of irrigation by WW compared to that by PWW.

For Acacia farnesiana (Figure 7), the same period of adaptation of the plants was found, as well as, an increasingly significant difference between the treatments: The average diameter of the plants irrigated with WW reached $4.59 \mathrm{~mm}$ against $1.98 \mathrm{~mm}$ for plants irrigated by PWW, indicating that the difference was statistically significant $(P<0.05)$.

For Leucaena leucocephala (Figure 8), beyond the 6 th week, the difference in growth increased until the end of the experiment. In terms of the influence of the quality of irrigation water on plants, the same trend as for Acacia farnesiana was found. Plants irrigated with WW developed to an average diameter of $3.92 \mathrm{~mm}$ compared to $2.06 \mathrm{~mm}$ for those irrigated with PWW; the difference was statistically significant $(P<0.05)$.

Statistical analyses of biometric measurements over 25 weeks confirmed that there is a highly significant difference (Table 2).

The boxplot showed that the growth of PWW-irrigated plants is much higher than that of the WW-irrigated plants, both in height and diameter (Figures 9 and 10).

\section{Discussion}

According to the obtained results shown in Table 1, in both types of water, the salinity of the water is confirmed but to different degrees: The WW $(2.49 \mathrm{dS} / \mathrm{m})$ shows high salinity, while the PWW $(13.51 \mathrm{dS} / \mathrm{m})$ is considered to be water with exaggerated salinity (41). The salinity level of

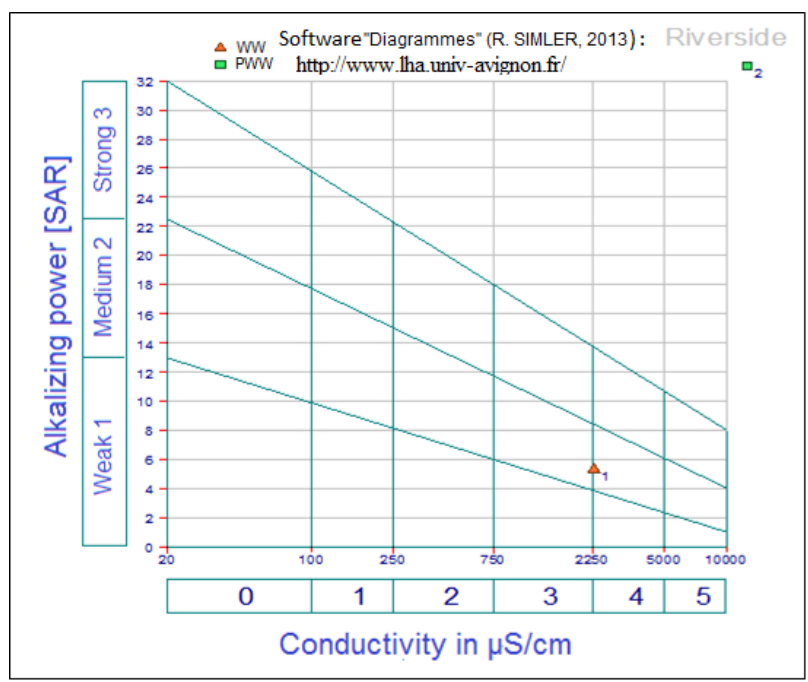

Figure 4. Riverside's diagram for irrigation water. 


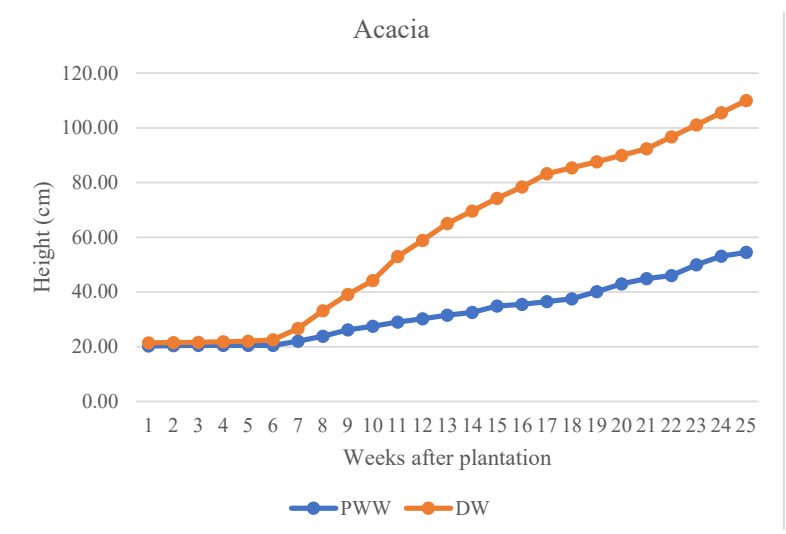

Figure 5. Height growth curves of $A$. farnesiana.

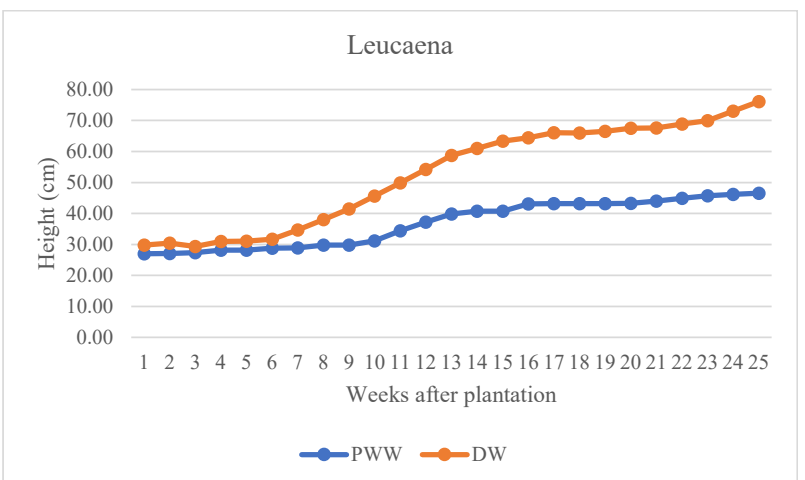

Figure 6. Height growth curves of L. leucocephala

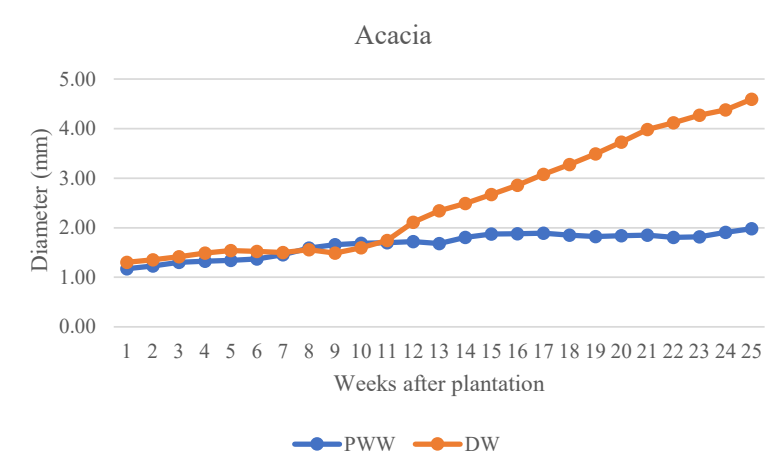

Figure 7. Diameter growth curves of $A$. farnesiana.

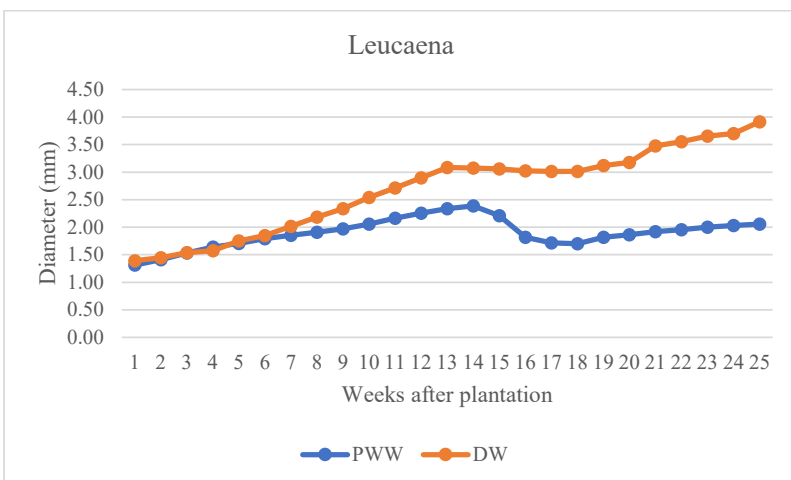

Figure 8. Diameter growth curves of $L$. leucocephala. the latter (PWW) was found to be close to that reported by Nader (39) and Bouhana et al (40), 12.68 and $13.39 \mathrm{dS} / \mathrm{m}$, respectively.

The SAR value is 41.25 for PWW, which is very high compared to 5.30 for WW. In this case, the PWW caused serious problems on the structure of the soil, resulting in poor drainage of the latter. On the other hand, Nader (39) recorded a low value equal to 13.95 (almost one-third), this variation is all dependent on the concentrations of sodium, calcium, and magnesium.

The concentration of chlorides in the PWW (106 $\mathrm{meq} / \mathrm{L})$ is 10 times the authorized value $(10 \mathrm{meq} / \mathrm{L})$, according to the Algerian standards (42). In the WW, the chloride concentration is $11.97 \mathrm{meq} / \mathrm{L}$, which is very close to the accepted standard.

The pollution parameters recorded in Table 1 and analyzed according to the Algerian standards (42) show that:

- The average value of BOD5 for the study period is equal to $27 \mathrm{mg} / \mathrm{L}$, which is below the value recommended in the Algerian standards $(30 \mathrm{mg} / \mathrm{L})$.

- The average COD value was equal to $132 \mathrm{mg} / \mathrm{L}$, which

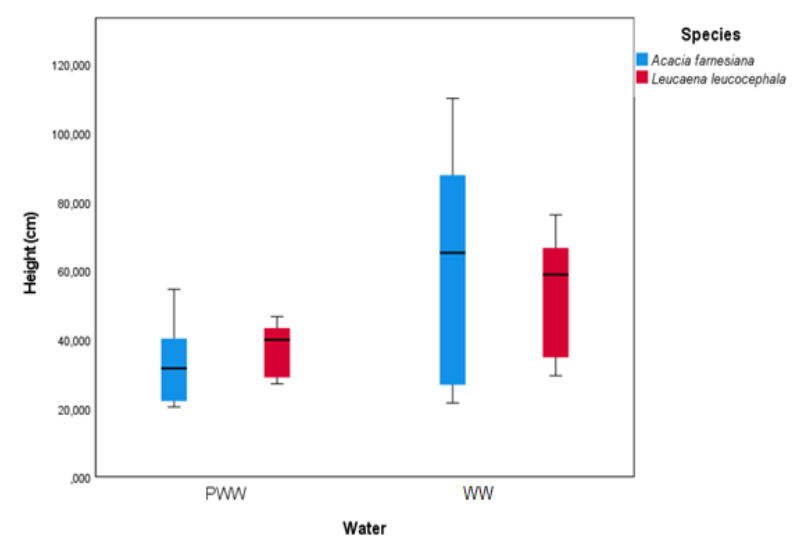

Figure 9. Box plot showing the variation in height according to the quality of the water used.

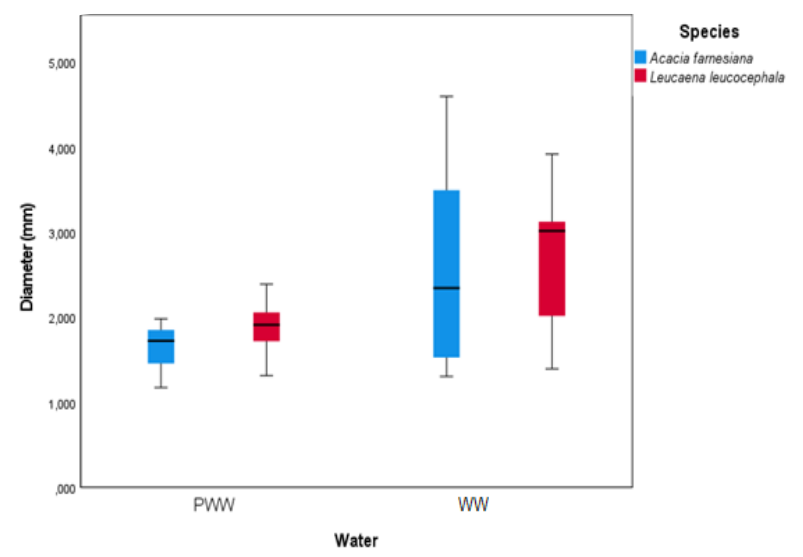

Figure 10. Box plot showing the variation in diameter according to the quality of the water used. 
Table 2. Statistical analysis of biometric measurements (95\% of confidence interval)

\begin{tabular}{|c|c|c|c|c|c|c|c|c|}
\hline \multirow{2}{*}{ Variable } & \multirow{2}{*}{ Contrast } & \multirow{2}{*}{$\mathrm{N}$ or DF } & \multicolumn{2}{|c|}{ PWW } & \multicolumn{2}{|r|}{ WW } & \multirow{2}{*}{ Test Value } & \multirow{2}{*}{$P$ value } \\
\hline & & & Mean & Standard Deviation & Mean & Standard Deviation & & \\
\hline \multirow{2}{*}{ Height (cm) } & Acacia & 25 & 32.851 & 11 & 61.003 & 31.256 & $t=-4.248$ & $0.000^{* *}$ \\
\hline & Leucaena & 25 & 36.892 & 7.404 & 52.648 & 16.515 & $U=137$ & $0.001 * *$ \\
\hline \multirow{2}{*}{ Diameter (mm) } & Acacia & 25 & 1.661 & 0.242 & 2.555 & 1.13 & $U=198.5$ & $0.000^{* *}$ \\
\hline & Leucaena & 25 & 1.897 & 0.269 & 2.684 & 0.771 & $\mathrm{t}=-4.816$ & $0.000 * *$ \\
\hline
\end{tabular}

t: t-test, $U:$ Mann-Whitney $U$ test, ${ }^{* *}$ : Highly significant

exceeds the value recommended in the Algerian standards $(90 \mathrm{mg} / \mathrm{L})$.

- The average value was equal to $90 \mathrm{mg} / \mathrm{L}$ for suspended solids (SS). This value far exceeds the accepted Algerian standard (30 mg/L). This high SS value is mainly due to eutrophication (significant development of algae and phytoplankton in the ponds).

Both types of water are of poor quality, highly mineralized, which may only be suitable for species that are well tolerant to salts and on well-drained and leached soils. According to Durand (41), the use of these waters will require certain precautions.

The obtained results show the influence of the quality of irrigation water on the development and growth of plants within the framework of this experiment, it essentially emerges that the plants of the two species irrigated with WW experienced a growth (height and diameter) much greater than those irrigated by the PWW from the Ouargla WWTP. In terms of interspecies comparison, Leucaena showed a better behavior (height and diameter) compared to Acacia when the species were irrigated by the PWW.

However, Acacia showed better resistance to edaphohydro-climatic conditions, this is judged on the basis of the number of individuals that persisted until the end of the experiment, namely:

* Block watered by WW: Acacia is $75 \%$, Leucaena is $70.83 \%$.

* Block watered by PWW: Acacia is $54.16 \%$, Leucaena is $25 \%$.

These results are not consistent with the results of the studies by Laouali et al (43) on Acacia nilotica (L.) Wild., Prosopis juliflora, Azadirachta indica, Cassia siamea Lam., and Delonix regia (Boj.) Raf., using raw wastewater, Idder et al (44) on Leptadenia hastata and Moringa Oleifera irrigated by wastewater with compost, Fatma and Hayssam (15) on Acacia saligna and Leucaena leucocephala irrigated by PWW, and a study by Zouari et al (45) in the northern of Tunisia on five agroforestry species (Atriplex nummularia, Eucalyptus gomphocephala, Acacia cyanophylla, Casuarina glauca, and Pinus halepensis) irrigated by treated wastewater, where the results were positive especially on biomass production. Thus, these plants have additional positive effects on the soil properties especially $\mathrm{pH}$ and EC.
It is worth mentioning that the experiment was performed in a Saharan environment which is characterized by a high temperature and a wind regime that results in hot and dry winds (sirocco), whose surface layers can heat up during the day up to $70^{\circ} \mathrm{C}$ according to Ozenda (46). In addition, the low growth rate of plants, mainly those irrigated by PWW, can be explained by the level of salinity which increases the osmotic potential and makes water unavailable, and subsequently, causes growth retardation (41,47-49).

\section{Conclusion}

The results of analyses performed on the PWW from the Ouargla WWTP do not comply with the standards of the Algerian regulations. These types of water belong to the latest Riverside's C5-S4 class, with an electrical conductivity that reaches $13.51 \mathrm{dS} / \mathrm{m}$, resulting in the high risk of salinization.

The results of monitoring the species studied showed that watering plants with PWW has a less interesting effect compared to that with WW. Despite this, it should be noted that this preliminary study was mainly conducted to demonstrate that the reuse of treated effluents from the Ouargla WWTP is possible, and would therefore, make it possible to a certain extent to save WW, which are fossil waters.

For the use of this water for all agricultural purposes, its physicochemical quality, in particular, must be taken into account:

Its electrical conductivity (EC), which can be remedied either by adding WW to the PWW in order to minimize the concentration of soluble salts, or by choosing crops and other cultures that tolerate salinity (biosaline agriculture).

Its SS, which cause clogging of the irrigation network, require tertiary treatment.

Further studies should be conducted, for the plot studied, over longer periods in order to deepen the impacts of PWW on the plant, soil, and water table, and thus, to determine to what extent we can reduce the health and environmental risks associated with the reuse of these water resources.

\section{Acknowledgments}

The authors would like to thank all those who contributed to this work, the staff of the following laboratories: ONA, LEC, ADE 
and ANRH for their contribution to the realization of this work. In addition, special thanks to the students of master ecology especially NEKHLA OK and REMOUNE K who participated in this study.

\section{Ethical issues}

The authors certify that this manuscript is the original work of the authors, and all data collected during the study are presented in the manuscript, and no data from the study has been or will be published elsewhere separately.

\section{Competing interests}

The authors declare that they have no conflict of interests.

\section{Authors'contributions}

All authors contributed to data collection, analysis, and interpretation. All authors reviewed, refined, and approved the manuscript.

\section{References}

1. Solutions for a water-short world. Popul Rep M 1998; 14: 1-31.

2. OMS. Utilisation sans risque des eaux usées, des excreta et des eaux ménagères [Internet]. WHO. World Health Organization; [cité 22 avr 2021]. Available from: https://apps.who.int/iris/bitstream/ handle/10665/78280/9789242546835_fre.pdf? sequence $=3$. doi.org/10.1787/888933388028. [In French].

3. Safar-Zitoun M. Plan national secheresse algerie, lignes directrices en vue de son operationnalisation. [cited 2021 Apr 22] Available from: https://knowledge.unccd.int/ sites/default/files/country_profile_documents/Plan $\% 20$ National\%20S\%C3\%A9cheresse\%20Alg\%C3\%A9rie\%20 version3.2\%20d\%C3\%A9f.300619-3-version-20-12-2019converti.pdf.

4. Benblidia M, Thivet G. Gestion des ressources en eau : les limites d'une politique de l'offre. 2010;15. Available from: http://portail2.reseau-concept.net/Upload/ciheam/ fichiers/NAN58.pdf. [In French].

5. Mozas M, Ghosn A. État des lieux du secteur de l'eau en Algérie. [cited 2020 Apr 17] Available from: http://www. ipemed.coop/fr/publications-r17/etudes-analyses-c108/ Etat-des-lieux-du-secteur-de-leau-en-algerie-a2150.html. [In French].

6. Winpenny J, Heinz I, Koo-Oshima S. Reutilización del agua en agricultura: beneficios para todos? [cited 2020 Apr 17] Available from: http://www.fao.org/3/i1629s/i1629s.pdf. [In French].

7. Ali HM, Siddiqui MH, Khamis MH, Hassan FA, Salem MZ, El-Mahrouk EM. Performance of forest tree Khaya senegalensis (Desr.) A. Juss. under sewage effluent irrigation. Ecological Engineering 2013; 61(Part A): 117-26. doi: 10.1016/j.ecoleng.2013.09.051.

8. Al-Yamani W, Green S, Pangilinan R, Dixon S, Shahid SA, Kemp P, et al. The impact of replacing groundwater by treated sewage effluent on the irrigation requirements of Al Ghaf (Prosopis cineraria) and Al Sidr (Ziziphus spinachristi) forests in the hyper-arid deserts of Abu Dhabi. Agricultural Water Management 2019; 214: 28-37. doi: 10.1016/j.agwat.2018.12.031.
9. Zonn IS, Kostianoy AG, Semenov AV. The Western Arctic Seas Encyclopedia. Switzerland: Springer International Publishing; 2017.

10. Moscoso J. Aspectos técnicos de la agricultura con aguas residuales. Lima Cent Panam Ing Sanit Cienc Ambiente CEPIS Organ Panam Salud OPS. 1995; [In French].

11. Minhas PS, Khajanchi-Lal, Yadav RK, Dubey SK, Chaturvedi RK. Long term impact of waste water irrigation and nutrient rates: I. Performance, sustainability and produce quality of peri urban cropping systems. Agricultural Water Management 2015; 156: 100-9. doi: 10.1016/j.agwat.2015.03.012.

12. Saeed Abuzaid A. Sewage effluent as an alternative source for irrigation: Impact on soil properties and heavy metalstatus. Moshtohor 2016; 54(2): 387-96. doi: 10.21608/ assjm.2016.104130.

13. Ali HM, EL-Mahrouk EM, Hassan FA, EL-Tarawy MA. Usage of sewage effluent in irrigation of some woody tree seedlings. Part 3:Swietenia mahagoni(L.) Jacq. Saudi Journal of Biological Sciences 2011; 18(2): 201-7. doi: 10.1016/j.sjbs.2010.08.001.

14. Al-Yamani W, Kennedy L, Green S, Kemp P, Clothier B. The historical basis and future options for native plant-species in the hyper-arid forests of Abu Dhabi. Land Use Policy 2019; 88: 104186. doi: 10.1016/j.landusepol.2019.104186.

15. Fatma AH, Hayssam MA. Impact of irrigation with sewage effluent on the growth and wood properties of two forest tree seedlings. Journal of Forest Products and Industries 2013; 2(2): 40-44.

16. Braatz $\mathrm{S}$, et Kandiah A. Recyclage des eaux usées urbaines pour l'irrigation des forêts et des arbres, Unasylva 1996; 47(185): 45-51. [In French].

17. Edgar JG, Stewart HT. Wastewater disposal and reclamation using eucalyptus and other trees. Progress in Water Technology; 1979.

18. Ayers RS, Westcot DW. Water Quality for Agriculture. Irrigation and Drainage. Rome, Italy: FAO; 1976.

19. Ziaei Hezarjaribi H, Yousefi Z, Rahimi Esboei B. Efficiency of wastewater treatment plants in removal of intestinal parasites: A review approach. Environmental Health Engineering and Management Journal 2020; 7(3): 171-81. doi: 10.34172/EHEM.2020.20.

20. Toze S. PCR and the detection of microbial pathogens in water and wastewater. Water Res 1999; 33(17):3545-56. doi: 10.1016/S0043-1354(99)00071-8.

21. Talepour N, Hassanvand MS, Abbasi-Montazeri E, Latifi SM, Jaafarzadeh Haghighi Fard N, Shenavar B. Identification of airborne fungi's concentrations in indoor and outdoor air of municipal wastewater treatment plant. Environmental Health Engineering and Management Journal 2020; 7(3): 143-50. doi: 10.34172/EHEM.2020.17.

22. Côte M. Des oasis malades de trop d'eau? Sci Chang PlanétairesSécheresse 1998; 9(2): 123-30. [In French].

23. Coté M. La ville et le désert: le Bas-Sahara algérien. Karthala Éditions; 2005. [In French].

24. Dubost D. Ecologie, aménagement et développement agricole des oasis algériennes [Thèse]. Bienvenue au CRSTRA, Centre de recherche scientifique et technique sur les régions arides; 2002. 423 p. [In French].

25. Idder T. La dégradation de l'environnement urbain liée aux 
excédents hydriques au Sahara algérien. Impact des rejets dorigine agricole et urbaine et techniques de remédiation proposées. L'exemple de Ouargla [dissertation]. Angers: Université d’Angers; 1998. [In French].

26. Idder $\mathrm{T}$, Idder A, Tankari Dan-Badjo A, Benzida A, Merabet S, Negais H, et al. Les oasis du Sahara algérien, entre excédents hydriques et salinité. Revue Des Sciences De L'Eau 2014; 27(2): 155-64. doi: 10.7202/1025565ar. [In French].

27. Negais H. L'effet du projet d'assainissement des eaux résiduaires, pluviales et d'irrigation sur l'écosystème oasien, cas du chott Ain Beida et chott d'Oum Erraneb [dissertation]. Ouargla: Université Kasdi Merbah Ouargla; 2007. p. 113. [In French].

28. Azizi A, Tahri T, Sellami MH, Segni L, Belakroum R, Loudiyi K. Experimental and CFD investigation of smallscale solar chimney for power generation. Case study: southeast of Algeria. Desalination Water Treat 2019; 160:18. doi:10.5004/dwt.2019.24167.

29. Fergougui MME, Benyamina H, Boutoutaou D. Abacus to determine soils salinity in presence of saline groundwater in arid zones case of the region of Ouargla. AIP Conference Proceedings 1968; 030051 (2018). doi. org/10.1063/1.5039238.

30. Monteverdi MC, DaCanal S, Del Lungo A, Masi S, Larbi H, De Angelis P. Re-use of wastewater for a sustainable forest production and climate change mitigation under arid environments. Annals of Silvicultural Research 2014; 38(1): 22-31. doi: 10.12899/ASR-778.

31. Wikipedia. Ouargla. [cited 2021 August 4] Avalable frome: https://en.wikipedia.org/wiki/Ouargla.

32. Rouvillois-Brigol M. Le pays de Ouargla (Sahara algérien): variations et organisation d'un espace rural en milieu désertique/Madeleine Rouvillois-Brigol. EParis: Universite de Paris-Sorbonne, 1975. [In French].

33. Negais $\mathrm{H}$. La réutilisation des effluents urbains traités par lagunage dans la cuvette de Ouargla. Etats des lieux, enjeux et perspectives [dissertation]. Ouargla: Université Kasdi Merbah Ouargla; 2015. p. 129. [In French].

34. Rodier J. L’analyse de l'eau: eaux naturelles, eaux résiduaires, eau de mer: chimie, physico-chimie, bactériologie, biologie. 6th ed. Paris: Dunod; 1978. [In French].

35. Shelton HM, Brewbaker JL. Leucaena leucocephala-the most widely used forage tree legume. Wallingford, UK: CAB International; 1994. p. 15-29.

36. TerMeulen U, El-Harith EA. Mimosine-a factor limiting the use of Leucaena leucocephala as an animal feed. Journal of Agriculture in the Tropics and Subtropics 1985; 86(2): 109-27.

37. Benbrahim KF, Berrada H, El Ghachtouli N, Ismaili M. Les acacias: des plantes fixatrices d'azote prometteuses pour le développement durable des zones arides et semi-arides
(Acacia: Promising Nitrogen fixing trees for sustainable development in arid and semi-arid areas). Int J Innov Appl Stud 2014; 8(1): 46-58. [In French].

38. Erkovan Hİ, Clarke PJ, Whalley RD. A review on General Description of Vachellia farnesiana (L.) Wight \&Arn. Atatürk Üniversitesi Ziraat Fakültesi Derg 2016; 47(1): 716.

39. Nader A. Eaux usées épurées de la cuvette de Ouargla. Gestion et risques environnementaux [dissertation]. Ouargla: Université Kasdi Merbah Ouargla; 2015. p. 119. [In French].

40. Bouhana A, Bouhoun MD, Idder T. Impacts of treated wastewater on the halomorphic phoenicicultural environment in ouargla basin (northern algerian sahara). Ponte Academic Journal 2019; 75(7). doi: 10.21506/j. ponte.2019.7.2.

41. Durand JH. Contribution à létude des sols irrigués. Lévolution Sols Sous L'influence L'irrigation. Travaux des Sections Pédologie et Agrologie 1960; 6: 13. [In French].

42. Journal Officielde La Republique Algerienne Democratique Et Populaire. Conventions Et Accords Internationaux - Lois Et Decretsarretes, Decisions, Avis, Communications Et Annonces. [cited 2020 Oct 25] Available from: https://and. $\mathrm{dz} /$ site/wp-content/uploads/Arrete-interministeriel-du2janvier-2012.pdf. [In French].

43. Laouali G, Delisle CE, Vincent G. Étude préliminaire de réutilisation des eaux usées pour l’arrosage des pépinières au Niger. Water Quality Research Journal 1996; 31(1): 37 50. doi: 10.2166/wqrj.1996.003. [In French].

44. Idder T, Laouali S, Boubakar Y, Kwa R, Mahmoudou A. Etude préliminaire de l'utilisation des sous produits du lagunage pour l'arrosage au niger. La Tribune de l'eau 2005; 58(635): 3-9. [In French].

45. Zouari M, Souguir D, Bloem E, Schnug E, Hanchi B, Hachicha M. Saline soil reclamation by agroforestry species under Kalaât Landelous conditions and irrigation with treated wastewater in Tunisia. Environ Sci Pollut Res 2019; 26(28): 28829-41. doi: 10.1007/s11356-019-06086-x.

46. Ozenda P. Flore du Sahara. 2nd ed. Paris: National Center for Scientific Research; 1977. [In French].

47. Soltner D. Les bases de la production végétale. [Cited 2021 Apr 27] Available from: https://soltner.fr/agronomie/Lesbases-de-la-production-vegetale-tome-i-le-sol/. [In French].

48. Agence de Bassin Hydrographique Sahara. Lutilisation des eaux usées épurées en irrigation. [cited 2021 Apr 11] Available from: https://www.riob.org/fr/file/264186/ download?token=JNzfYevZ. [In French].

49. Drechsel P, Scott CA, Raschid-Sally L, Redwood M, Bahri A. L'irrigation avec des eaux usées et la santé: évaluer et atténuer les risques dans les pays à faible revenu. Quebec: University Of Quebec Press; 2011. doi: 10.2307/j. ctv18pgj60. [In French]. 